\title{
Clavibacter michiganensis subsp. sepedonicus Elicits a Hypersensitive Response in Tobacco and Secretes Hypersensitive Response-Inducing Protein(s)
}

\author{
R. Nissinen, F.-M. Lai, M. J. Laine, P. J. Bauer, A. A. Reilley, X. Li, S. H. De Boer, C. A. Ishimaru, and M. C. Metzler
}

First, third, and ninth authors: Department of Biology, Laboratory of Plant Physiology and Molecular Biology, University of Turku, Biocity 6A, Turku, Finland; second, fourth, fifth, and eighth authors: Department of Bioagricultural Sciences and Pest Management, Colorado State University, Fort Collins 80523-1177; sixth author: TerraGen Diversity Inc., Ste. 300, 2386 E. Mall, Vancouver, BC V6T 1Z3, Canada; seventh author: Centre for Animal and Plant Health, 93 Mount Edward Rd., Charlottetown, PEI C1A 5T1, Canada.

Accepted for publication 24 April 1997.

\begin{abstract}
Nissinen, R., Lai, F.-M., Laine, M. J., Bauer, P. J., Reilley, A. A., Li, X., De Boer, S. H., Ishimaru, C. A., and Metzler, M. C. 1997. Clavibacter michiganensis subsp. sepedonicus elicits a hypersensitive response in tobacco and secretes hypersensitive response-inducing protein(s). Phytopathology 87:678-684.

Strains of Clavibacter michiganensis subsp. sepedonicus, causal agent of bacterial ring rot of potato, showed marked differences in virulence on host plants. When infiltrated into tobacco leaves, virulent strains caused a rapid localized necrotic response (within 24 to $48 \mathrm{~h}$ ) characteristic of the hypersensitive response (HR), whereas nonpathogenic strains did not.

tease sensitive. Inhibitors of eukaryotic metabolism suppressed the necrotic reaction of tobacco to CCS. No necrotic response was observed when host plants were infiltrated with either cells or CCS from virulent strains. HR-inducing protein(s) from a virulent strain separated from the majority of other proteins on DEAE cellulose at 250 to $300 \mathrm{mM} \mathrm{NaCl}$. Ammonium sulfate-precipitated proteins from a virulent strain produced a necrotic reaction at a total protein concentration of $18 \mu \mathrm{g} / \mathrm{ml}$, whereas those from a nonpathogenic strain did not, even at a concentration of 180 $\mu \mathrm{g} / \mathrm{ml}$. We conclude that virulent strains of $C$. michiganensis subsp. sepedonicus elicit a typical HR in tobacco and secrete proteinaceous elicitor(s) of the nonhost HR.
\end{abstract} Concentrated cell-free culture supernatants (CCS) from virulent strains caused a necrotic reaction on tobacco, whereas CCS from nonpathogenic strains did not. The necrosis-inducing activity was heat stable and pro-
Additional keywords: Corynebacterium sepedonicum.
The gram-positive bacterium Clavibacter michiganensis subsp. sepedonicus causes bacterial ring rot of potato (16). In recent years, the number of crop failures due to this disease has been reduced by widespread adoption of a limited generation certified seed program in which there is zero tolerance for the disease (27, 42). However, eradication of the disease has not yet been achieved (19-21,42). Certification of seed lots based on pathogen detection rather than symptom detection is being implemented to limit the spread of latent infections, which are especially common in resistant cultivars and climates unconducive to symptom expression. The pathogen is spread during harvesting, storage, and cutting of tubers to produce seed pieces. Disease severity is affected by the environment (54), cultivar $(7,18,28,41)$, and pathogen strain $(7,11)$. Despite interest in elucidating the molecular biology of pathogenesis in C. michiganensis subsp. sepedonicus, progress has lagged behind that of gram-negative phytopathogens due to a lack of methods for genetic analysis of this and other coryneform bacteria. Recently, methods have been developed for transformation of C. michiganensis subsp. sepedonicus and related subspecies (38, 43); however, other basic tools, such as transposons and marker exchange methods, remain to be developed.

Biological interactions useful for studying pathogenicity of bacteria on plants need not be limited to those involving disease. On the contrary, studies of incompatibility, which results from the in-

Corresponding authors: C. Ishimaru and M. Metzler

E-mail addresses: cishimar@lamar.colostate.edu and metzler@sara.cc.utu.fi

Publication no. P-1997-0521-01R

(C) 1997 The American Phytopathological Society teraction of a pathogen with a nonhost or a resistant host, have proven very productive. For example, several genera of gram-negative phytopathogenic bacteria elicit a hypersensitive response (HR), visible macro- and microscopically as rapid, localized plant cell death, when infiltrated into leaves of a nonhost plant, such as tobacco $(25,36)$. From numerous studies, it is known that the $h r p$ gene clusters in Erwinia amylovora (9), Xanthomonas campestris $(3,13)$, Pseudomonas syringae $(39,46)$, and Ralstonia solanacearum (14) are required for HR induction on nonhosts and for pathogenicity on hosts (26). Avirulence genes also are required to elicit a HR on resistant host cultivars, and evidence is mounting that Avr proteins transit the $h r p$-encoded secretion system $(1,48)$.

Induction of an HR-like reaction by a gram-positive plant pathogen was first described with the discovery of a hypersensitivelike reaction induced on four o'clock (Mirabilis jalapa) and tobacco by $C$. michiganensis subsp. michiganensis (24). All strains that were pathogenic on tomato also induced a hypersensitive-like reaction on four o'clock (24), agreeing with observations first made by Klement (37) that linked elicitation of the HR to pathogenicity in gram-negative bacteria. We have never successfully induced an HR on M. jalapa infiltrated with C. michiganensis subsp. sepedonicus (C. Ishimaru and M. Metzler, unpublished data); however, we find that this bacterial species does induce a necrotic response on tobacco. We demonstrate here that virulent strains produce a necrotic response, resembling the HR, on tobacco, whereas spontaneously attenuated nonpathogenic strains do not. We provide evidence that this necrotic response is a true HR, and we further show that an HR on tobacco can be elicited by preparations of extracellular proteins produced only by virulent strains. We also present a partial purification of HR-inducing protein(s). 


\section{MATERIALS AND METHODS}

Bacterial strains. The $C$. michiganensis subsp. sepedonicus strains used in this study were obtained from various sources. All originally were isolated from infected potatoes (Table 1). Strains 3M, 3NM, Cs4, R5, and R8 are spontaneously attenuated strains, and their identity as $C$. michiganensis subsp. sepedonicus was confirmed by immunofluorescence and polymerase chain reaction (34). Strains were stored at $-80^{\circ} \mathrm{C}$ in DM medium (45) containing $20 \%$ glycerol. They were grown in either DM or YGM medium (17), either on agar or in liquid on a rotary shaker $(280 \mathrm{rpm})$ at $26^{\circ} \mathrm{C}$. Escherichia coli DH5 $\alpha$ (Clontech, Palo Alto, CA) was grown on $2 \times$ YT agar (50) at $37^{\circ} \mathrm{C}$. Erwinia amylovora strain 3305 and $R$. solanacearum 3238 biovar IV (National Collection of Plant Pathogenic Bacteria, Harpenden, England) were grown at $29^{\circ} \mathrm{C}$ on nutrient broth-yeast extract medium (51) and YGM, respectively.

Virulence tests. Virulence of $C$. michiganensis subsp. sepedonicus strains was evaluated in potato (Solanum tuberosum L.), the only natural host, and eggplant (S. melongena L.), an artificial host commonly used as an indicator plant. Eggplants (cv. Black Beauty) that were 28-days old were grown in a greenhouse and inoculated by injecting stems at a single site with $\sim 20 \mu$ of bacterial suspension $\left(10^{8}\right.$ cells per $\left.\mathrm{ml}\right)$ in quarter-strength Ringer's solution (55). Daytime conditions were $24^{\circ} \mathrm{C}$, with a 15 -h photoperiod supplemented with sodium vapor lights, and the nighttime temperature was $19^{\circ} \mathrm{C}$. Foliar wilt severity was rated 18 days after inoculation, using the 1 to 12 double-logarithmic Horsfall-Barratt scale (33), in which 1 indicates no symptoms and 12 indicates visible symptoms on $100 \%$ of the plant. Results from a minimum of six plants per strain were averaged to obtain mean values of virulence.

S. tuberosum cv. Red Pontiac was used to evaluate virulence in potato. Plantlets were generated by micropropagating stem sections as previously described $(23,35)$. After 21 to 28 days, plantlets were removed from tissue-culture medium. To promote bacterial entry, plantlet roots were trimmed aseptically to remove about one-third of the advancing root mass and immersed in a cell suspension of each strain. After soaking for $30 \mathrm{~min}$, the plantlets were planted in soil. Six plantlets per strain were included to calculate the mean severity of foliar wilt symptoms 12 weeks after inoculation, as described above for eggplant.

Test for necrotic response in tobacco. Tobacco plants (Nicotiana tabacum L. 'Samsun' and 'Xanthi' ['Turk']) were grown in soil in $10.5 \times 10.5-\mathrm{cm}$ pots, $13 \mathrm{~cm}$ deep, at 22 to $24^{\circ} \mathrm{C}$, with a photoperiod of $16 \mathrm{~h}$ of light, $8 \mathrm{~h}$ of dark, and a light intensity of 200 to $300 \mu \mathrm{E} \mathrm{m}^{-2} \mathrm{~s}^{-1}$. For infiltrations, Samsun or Xanthi plants (6-leaf stage) were used. When flowering Xanthi plants were used, they were shifted to $19^{\circ} \mathrm{C}$ for at least $24 \mathrm{~h}$ prior to infiltration. Bacterial suspensions at $\mathrm{OD}_{650}$ (optical density at $650 \mathrm{~nm}$ ) $=0.3$ (in $5 \mathrm{mM}$ potassium phosphate buffer, $\mathrm{pH} 7.0$ ) or $\mathrm{OD}_{650}=0.8$ (in distilled water), giving cell densities of $\sim 5 \times 10^{8}$ and $1.3 \times 10^{9}$ $\mathrm{CFU} / \mathrm{ml}$, respectively, were infiltrated into intercellular spaces of fully expanded tobacco leaves with a hypodermic syringe, with or without a 26-gauge needle. Infiltrated areas were monitored for development of necrosis for $48 \mathrm{~h}$ postinoculation (hpi). Five to six inoculations were done for each strain. The resulting reactions were given numeral values from 0 to 3 : $0=$ no reaction; $1=$ necrotic spots visible in infiltrated area; $2=$ tissue collapse and necrosis at margins of infiltrated region; and 3 = complete collapse and necrosis of the entire infiltrated area.

Preparation and concentration of cell-free culture supernatants (CCS) with elicitor activity. C. michiganensis subsp. sepedonicus strains Cs4, R5, Cs7, R14, and CIC31 were grown in YGM medium for 2 to 3 days until cultures reached an $\mathrm{OD}_{650} \approx 2.0$. Cells were removed by centrifugation $(10,000 \times g$ for $15 \mathrm{~min})$, and supernatant was sterilized by passage through $0.2-\mu \mathrm{m}$ cellulose acetate filters (Schleicher \& Schuell, Dassel, Germany). The sterile culture supernatant was concentrated with Centricon 10 miniconcentrators (Amicon, Beverly, MA) or Vivaspin 15-ml concen- trators (Vivasciences, Binbrook Lincolnshire, England), having a cut-off size of $10 \mathrm{kDa}$, and then was desalted by washing with 3 volumes of $50 \mathrm{mM}$ potassium phosphate buffer, $\mathrm{pH}$ 7.0. The resulting concentrated CCS was diluted with phosphate buffer to give a final concentration 3 - to 15 -fold higher than the original supernatant. Protein concentration was determined by the Biorad protein assay (Biorad, Hercules, CA).

To test specific activities of elicitor preparations, C. michiganensis subsp. sepedonicus strains CIC31 (virulent) and Cs4 (nonpathogenic) were grown in 2 liters of YGM medium (300 rpm at $26^{\circ} \mathrm{C}$ ) to an $\mathrm{OD}_{650} \approx 2.0$. Cells were removed by centrifugation, and the supernatant was filter sterilized as above. Phenylmethylsulfonyl fluoride (PMSF) was added to give a final concentration of 0.5 $\mathrm{mM}$. The supernatant was cooled to $4^{\circ} \mathrm{C}$, and ammonium sulfate was added to give $40 \%$ saturation. After overnight precipitation at $4^{\circ} \mathrm{C}$, the precipitated proteins were collected by centrifugation at $4^{\circ} \mathrm{C}$ at $10,000 \times g$ for $15 \mathrm{~min}$. The pellet was suspended in $30 \mathrm{ml}$ of $50 \mathrm{mM}$ potassium phosphate buffer, $\mathrm{pH} 7.0$, and concentrated and desalted with Vivaspin 15-ml filters as described above for concentrated CCS. These preparations were infiltrated into tobacco leaves after diluting to appropriate concentrations.

Characterization of elicitor activity in CCS. For tests of heat stability, $100-\mu \mathrm{l}$ samples of CCS were heated at $100^{\circ} \mathrm{C}$ for $10 \mathrm{~min}$ in a boiling water bath and cooled on ice and clarified by centrifugation at $14,000 \mathrm{rpm}$ for $10 \mathrm{~min}$ in a table-top microcentrifuge. To determine sensitivity to protease, $100-\mu$ l aliquots of CCS were treated with 30 to $40 \mu \mathrm{g}$ of proteinase $\mathrm{K}$ per mg of total sample protein and incubated at $37^{\circ} \mathrm{C}$ for $30 \mathrm{~min}$. The reaction was stopped by heating reaction mixtures for $5 \mathrm{~min}$ at $100^{\circ} \mathrm{C}$. As a control for the protease treatment, the protease inhibitor PMSF was added to CCS to a final concentration of $0.5 \mathrm{mM}$ in the presence and absence of proteinase K. PMSF-treated samples were incubated and heat treated as described for proteinase K-treated samples.

Partial purification of proteinaceous elicitor. Concentrated CCS (50×) from CIC31 and CS3NM was prepared as described above, except that the supernatants were resuspended in $20 \mathrm{mM}$ Bis-Tris (BT) buffer, pH 6.0. Samples (400 $\mu$ l) were loaded onto a DEAE cellulose column that had been equilibrated with BT buffer (bed volume $1.5 \mathrm{ml}$ ), and the column was washed with $10 \mathrm{ml}$ of BT buffer. Proteins were eluted with a sodium chloride step gradient in BT buffer, with $50 \mathrm{mM}$ increments from 50 to $300 \mathrm{mM}$, a $500 \mathrm{mM}$ step, and a final $950 \mathrm{mM}$ step. The fractions collected were concentrated and washed with BT buffer with Vivaspin concentrators and resuspended to a final 400- $\mu$ l volume. Extracellular polysaccharide concentrations were determined colorimetrically (22).

TABLE 1. Disease symptom expression and necrotic reaction (NR) induced by strains of Clavibacter michiganensis subsp. sepedonicus on hosts

\begin{tabular}{lccccc}
\hline Strain & Potato $^{\mathrm{a}}$ & Eggplant $^{\mathrm{a}}$ & $\begin{array}{c}\text { NR } \\
\text { index }^{\mathrm{b}}\end{array}$ & $\begin{array}{c}\text { Source } \\
\text { of strains }\end{array}$ & $\begin{array}{c}\text { Colony } \\
\text { morphology }\end{array}$ \\
\hline 3M & 1.00 & 1.17 & 0.0 & S. H. De Boer & Mucoid \\
3NM & 1.00 & 1.33 & 0.0 & S. H. De Boer & Nonmucoid \\
Cs4 & 1.00 & 1.00 & 0.0 & S. H. De Boer & Nonmucoid \\
R5 & 1.00 & 1.50 & 0.0 & S. H. De Boer & Mucoid \\
R8 & 1.33 & 1.33 & 0.0 & S. H. De Boer & Mucoid \\
Cs9 & 6.00 & 2.83 & 1.4 & B. Rogers & Mucoid \\
Cs7 & 6.83 & 6.00 & 2.0 & B. Rogers & Mucoid \\
Cs2 & 7.00 & 7.67 & 1.7 & R. J. Copeman & Mucoid \\
Cs3-2 & 7.17 & 6.33 & 2.2 & B. Rogers & Mucoid \\
R14 & 7.67 & 8.50 & 2.4 & S. H. De Boer & Mucoid \\
Cs3-1 & 8.50 & 3.67 & 0.5 & S. H. De Boer & Mucoid \\
3RC & 10.83 & 10.50 & 2.8 & S. H. De Boer & Mucoid \\
CIC31 & 6.5 & 8.75 & 2.7 & C. Ishimaru & Nonmucoid \\
\hline
\end{tabular}

a Symptoms were rated according to the Horsfall-Barratt scale (33), in which $1=$ no symptoms and $12=$ disease symptoms on $100 \%$ of the plant. Mean symptom ratings are based on six plants evaluated at 18 days postinoculation.

b Tested on tobacco cv. Xanthi, mean necrotic reaction rating (from 0 to 3 ) for five to six plants of each strain. 
Protein was loaded onto sodium dodecyl sulfate-10\% polyacrylamide gels (SDS-PAGE) (6) and silver stained (silver staining kit, protein, Pharmacia Biotech, Uppsala, Sweden) according to the manufacturer's instructions.

Characterization of the tobacco necrotic response, using metabolic inhibitors. Immediately prior to infiltration, cycloheximide, lanthanum chloride, and sodium vanadate were mixed with extracellular proteins from strain CIC31 prepared by $40 \%$ ammoniumsulfate precipitation, as described above, to give final inhibitor concentrations of $7.0 \times 10^{-5} \mathrm{M}, 1 \times 10^{-3} \mathrm{M}$, and $5 \times 10^{-5} \mathrm{M}$, respectively (30), and a final total protein concentration of $25 \mu \mathrm{g} / \mathrm{ml}$. As a negative control, the inhibitors were mixed with distilled water to the same final concentration. $\alpha$-Amanitin at $2 \times 10^{-4} \mathrm{M}$ was infiltrated into leaves $30 \mathrm{~min}$ before infiltration with the protein preparation (30). As a positive control, the protein preparation at the same final concentration was infiltrated into leaves without any added inhibitor.

\section{RESULTS}

C. michiganensis subsp. sepedonicus strains with different levels of virulence. We assayed 13 strains of $C$. michiganensis subsp. sepedonicus for pathogenicity and virulence on both egg-

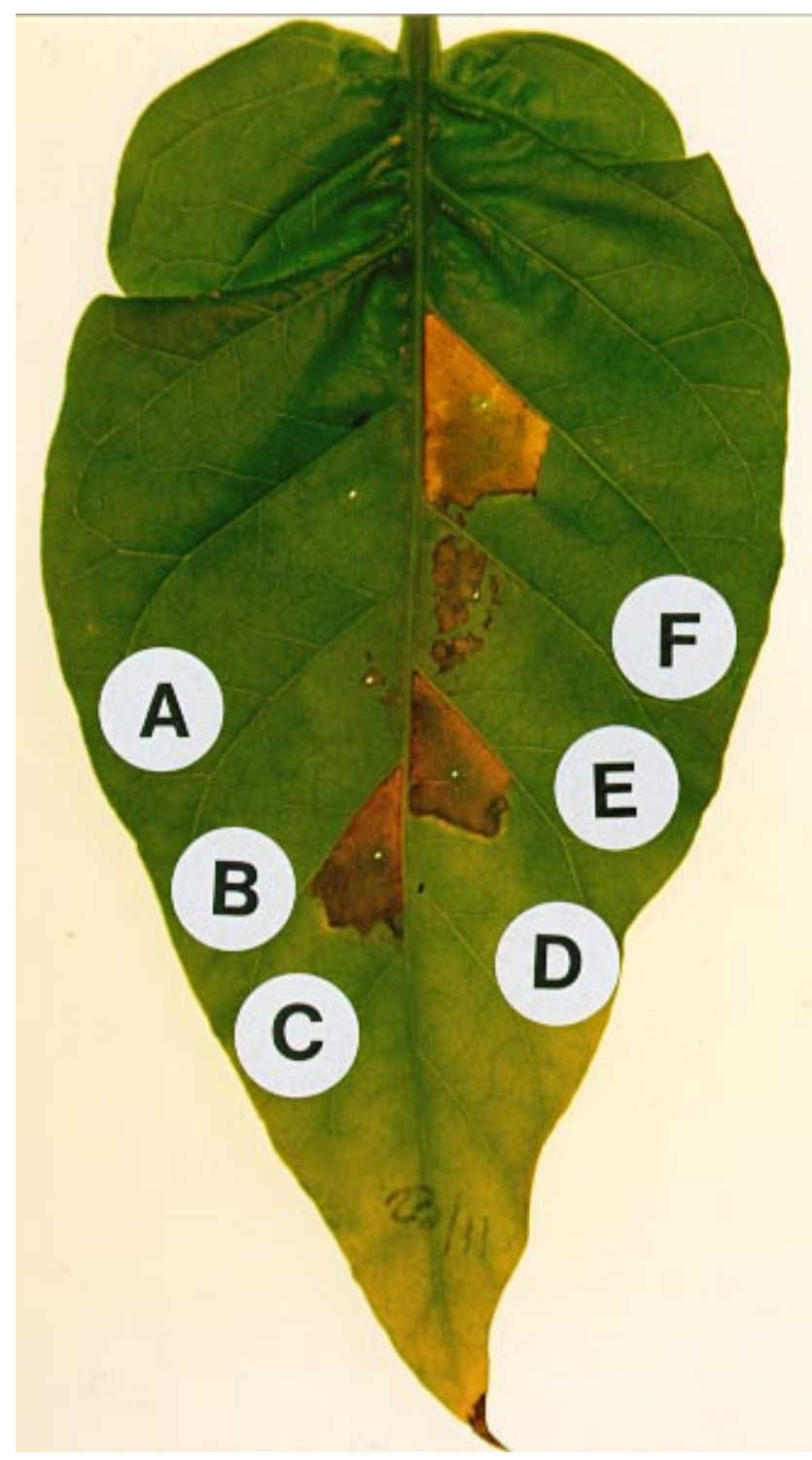

Fig. 1. Necrotic reaction elicited in tobacco cv. Xanthi leaves by virulent and nonpathogenic Clavibacter michiganensis subsp. sepedonicus strains $72 \mathrm{~h}$ postinoculation. Strains shown are A, R5; B, Cs3-1; C, Cs2; D, Cs7; E, Cs9; and F, R14. plant and potato. In both hosts, virulence of strains ranged from nonpathogenic to highly virulent (Table 1). All of the strains that were nonpathogenic on potato also were nonpathogenic on eggplant. Six of the strains that were highly virulent on potato (disease index > 6) also were highly virulent on eggplant. However, two strains showed higher virulence on potato than on eggplant: Cs3-1 caused severe symptoms on potato but showed only mild symptoms on eggplant, and Cs9 was moderately virulent on potato but weakly virulent on eggplant.

Correlation of virulence of different $C$. michiganensis subsp. sepedonicus strains with the ability to elicit a hypersensitivelike response on tobacco. Infiltration of a bacterial suspension of the highly virulent $C$. michiganensis subsp. sepedonicus strain R14 into tobacco leaves elicited a necrotic reaction resembling a HR. Plant tissue in the infiltrated area collapsed within $18 \mathrm{hpi}$ and became clearly necrotic at 24 to $36 \mathrm{hpi}$. By $48 \mathrm{hpi}$, the maximum response was observed, with the collapsed area becoming dry and papery (Fig. 1). No necrosis or chlorosis was observed beyond the infiltrated region. The reaction was slower than that obtained when leaves were infiltrated with E. amylovora, which showed a reac-

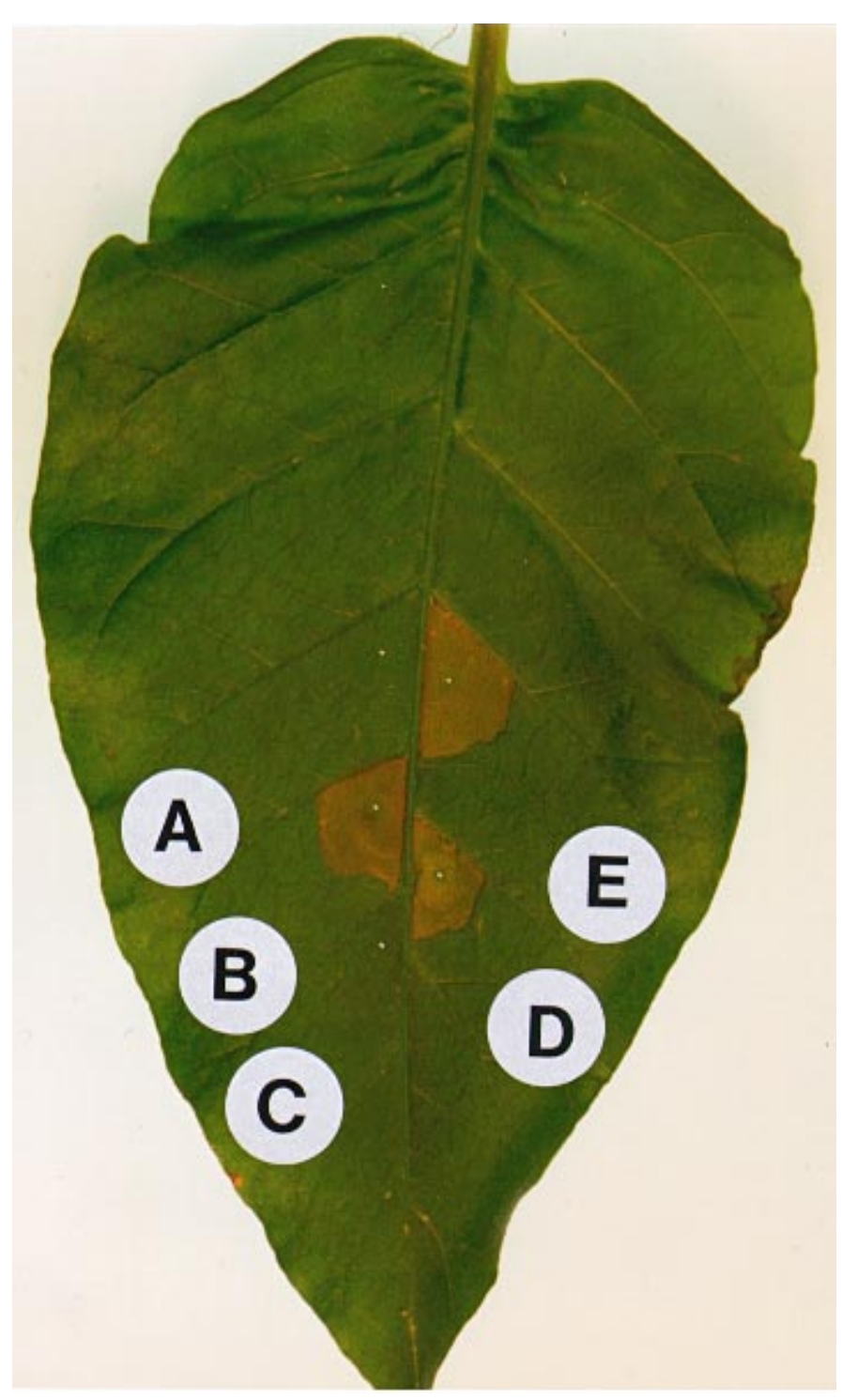

Fig. 2. Necrosis caused by $3 \times$ concentrated cellfree culture supernatant (CCS) of Clavibacter michiganensis subsp. sepedonicus in tobacco cv. Xanthi leaves $72 \mathrm{~h}$ postinoculation. A, Proteinase K-treated CCS from strain Cs7; B, heattreated CCS from strain Cs7; C, untreated CCS from strain R5 (negative control); D, untreated CCS from strain Cs7; and E, phenylmethylsulfonyl fluoridetreated CCS from strain Cs7. 
tion in less than $12 \mathrm{~h}$, but it was in all ways identical to that obtained with $R$. solanacearum. Similar infiltrations with Escherichia coli $\mathrm{DH} 5 \alpha$ did not cause a reaction.

We found the necrotic response induced by $C$. michiganensis subsp. sepedonicus on tobacco to be less reliable than the HR obtained with E. amylovora, in that it seemed to depend more on the growth conditions of the plant. The most reliable results were obtained with cv. Xanthi grown at a daytime temperature of $22^{\circ} \mathrm{C}$ and light intensity of $>300 \mu \mathrm{E} \mathrm{m}^{-2} \mathrm{~s}^{-1}$ or with cv. Samsun grown at a daytime temperature of $24^{\circ} \mathrm{C}$ and light intensity of $200 \mu \mathrm{E} \mathrm{m}^{-2} \mathrm{~s}^{-1}$.

When suspensions of each of the 13 C. michiganensis subsp. sepedonicus strains were infiltrated into leaves of Xanthi tobacco plants, they elicited differing degrees of necrosis (Table 1; Fig. 1). Strains that were nonpathogenic in both potato and eggplant did not cause a reaction on tobacco. Infiltrated areas appeared unaffected 72 hpi, although there was occasionally some slight chlorosis visible at 1 week postinfiltration. Highly virulent strains, i.e., those with disease indices greater than 6 on both potato and eggplant, usually triggered a strong localized necrotic response in tobacco (necrosis index of 1.7 to 3), similar to that caused by strain R14. The two strains that showed significantly different levels of virulence on potatoes and eggplant (Cs9 and Cs3-1) typically gave lower necrotic response indices, with collapse and necrosis occurring in patches rather than confluently throughout the infiltrated area (Fig. 1).

Induced necrotic response in tobacco by concentrated CCS. CCS from five strains was filtered to remove cells, desalted, and concentrated to $1 / 10$ the original volume. When infiltrated into tobacco, CCS from the virulent strains R14 and Cs7 caused collapse of the infiltrated area within $18 \mathrm{hpi}$, and necrotic lesions were clearly visible at $24 \mathrm{hpi}$. The reaction was identical in appearance to the response induced by living cells. CCS from three nonpathogenic strains, 3NM, Cs4, and R5, as well as Escherichia coli DH5 $\alpha$, did not cause a necrotic response.

Characterization of the necrotic response-inducing factor produced by $C$. michiganensis subsp. sepedonicus. CCS of strains Cs7 and R14 that had been treated with proteinase K no longer elicited a necrotic reaction on tobacco (Fig. 2). However, inactivation also occurred on some occasions in the absence of proteinase K. When PMSF, a protease inhibitor, was added to the nonproteinase K-treated CCS, the supernatants retained the ability to induce the necrotic reaction (Fig. 2). This suggests that $C$. michiganensis subsp. sepedonicus produces both proteinaceous factor(s) that induce the necrotic response in tobacco, as well as extracellular factor(s), possibly protease(s), that inactivate the elicitor. The inducing activity also was relatively heat stable: heat treating for $10 \mathrm{~min}$ at $100^{\circ} \mathrm{C}$ did not affect necrosis-inducing ability (Fig. 2). Therefore, necrotic response induction by CCS appeared to depend on heat-stable proteinaceous factor(s). Because the desalting process removed all molecules of less than $10 \mathrm{kDa}$, the necrosis-inducing factor(s) apparently were greater than $10 \mathrm{kDa}$.

Elicitor activities of CCS. Proteins from CCS of virulent strain CIC31 and nonpathogenic strain Cs4 were fractionated by precipitation with $40 \%$ ammonium sulfate and, subsequently, were desalted and concentrated 1,000-fold over that of the original culture supernatant. When infiltrated into tobacco, the preparation from
CIC31 gave a necrotic response at a protein concentration as low as $18 \mu \mathrm{g} / \mathrm{ml}$. The preparation from Cs4 was tested at concentrations up to $180 \mu \mathrm{g} / \mathrm{ml}$, and no response was seen on tobacco.

The necrotic response-an active plant defense reaction. The eukaryotic metabolic inhibitors cycloheximide, $\alpha$-amanitin, sodium vanadate, and lanthanum chloride were evaluated for their ability to interfere with the necrosis-inducing activity of CCS from virulent strain Cs7. CCS infiltrated into tobacco leaves along with metabolic inhibitors did not trigger any response, whereas the usual necrotic response was elicited in tobacco by untreated CCS (data not shown).

To confirm that the necrotic response was due to a nonhost plant defense reaction rather than a nonspecific toxin, leaves of cvs. Sangre and Ute Russet potato, as well as eggplant, were infiltrated with bacterial suspensions of virulent strains CIC31, Cs7, and R14, as well as concentrated CCS from CIC31 and R14. Neither bacterial cells nor CCS gave a rapid necrotic reaction in any of the host plants, although both induced a rapid necrotic response in tobacco. In contrast, E. amylovora elicited a strong HR in tobacco, potato, and eggplant. Furthermore, the ammonium sulfate-precipitated protein fraction from CIC31 did not induce a necrotic reaction on eggplant at a concentration of $180 \mu \mathrm{g}$ of total protein per $\mathrm{ml}$, although it induced a necrotic response on tobacco at $18 \mu \mathrm{g} / \mathrm{ml}$.

Partial protein purification. When CCS proteins from strains CIC31 (virulent) and CS3NM (nonpathogenic) were separated on DEAE cellulose, necrosis-inducing activity by CIC31 was eluted at 250 and $300 \mathrm{mM} \mathrm{NaCl}$. None of the fractions from CS3NM elicited a reaction (Table 2). SDS-PAGE of CCS from CIC31 and CS3NM showed many extracellular proteins (Fig. 3), as well as numerous differences between the two strains. In comparison, protein profiles of $250 \mathrm{mM}$ salt fractions from CIC31 and CS3NM contained fewer major bands. In addition to several minor differences, one major band at $\sim 25 \mathrm{kDa}$ appeared in the $250 \mathrm{mM} \mathrm{NaCl}$ DEAE cellulose fraction from CIC31 but not in the same fraction from CS3NM.

\section{DISCUSSION}

We report the induction of a rapid localized necrotic response in leaves of the nonhost tobacco when infiltrated with virulent strains of the gram-positive plant pathogen $C$. michiganensis subsp. sepedonicus. Within $18 \mathrm{~h}$, the infiltrated area collapsed, and by $36 \mathrm{~h}$, the entire infiltrated area was necrotic, with collapse and necrosis contained strictly within the infiltrated area. By $48 \mathrm{~h}$, the collapsed area was dry and papery. In contrast, induction of localized rapid necrosis was not observed in leaves of potato, the only known natural host of $C$. michiganensis subsp. sepedonicus, nor in eggplant, an artificial host. The necrotic reaction on tobacco was seen only with strains of $C$. michiganensis subsp. sepedonicus that were pathogenic on host plants. Strains that showed different levels of virulence on the two hosts tended to produce weaker, less reliable necrotic reactions. However, the lack of response of plants to nonpathogenic strains was consistent, in that nonpathogenic strains never induced localized necrosis.

The timing and localization of the necrotic reaction obtained in tobacco with $C$. michiganensis subsp. sepedonicus is the same as

TABLE 2. Hypersensitive response (HR) induced by DEAE cellulose fractions from Clavibacter michiganensis subsp. sepedonicus

\begin{tabular}{|c|c|c|c|c|c|c|c|c|c|c|}
\hline \multirow[b]{2}{*}{ Strain } & \multirow{2}{*}{$\begin{array}{c}\text { Total } \\
\text { protein }^{\mathrm{b}}\end{array}$} & \multicolumn{9}{|c|}{ Concentration of $\mathrm{NaCl}(\mathrm{mM})$ for eluted DEAE fractions $\mathrm{s}^{\mathrm{c}}$} \\
\hline & & 0 & 50 & 100 & 150 & 200 & 250 & 300 & 500 & 950 \\
\hline CIC31 (virulent) ${ }^{\mathrm{d}}$ & +++ & - & - & - & - & - & +++ & + & - & - \\
\hline 3NM (nonpathogenic) ${ }^{\mathrm{e}}$ & - & - & - & - & - & - & - & - & - & - \\
\hline
\end{tabular}

a A 30- $\mu$ l desalted sample was infiltrated into tobacco cv. Xanthi and scored at 24 h postinoculation. $+=$ mild HR; +++ = strong HR; and $-=$ no HR.

b Cellfree culture supernatants were concentrated, desalted, and brought up to $400 \mu$ l with Bis-Tris (BT) buffer before loading on the column.

${ }^{\mathrm{c}}$ Each fraction was concentrated, desalted, and brought up to $400 \mu \mathrm{l}$ with BT buffer before infiltration.

d Two hundred, twenty micrograms of total protein was loaded on the column.

e Three hundred, eighty micrograms of total protein was loaded on the column. 
that for the HR described for gram-negative plant pathogens, which elicit an HR on tobacco at 8- to 24-h postinfiltration, depending on the bacterial species (32). Given the resemblance between the necrotic reaction we observe in tobacco and the HR described for gram-negative pathogens in terms of timing, localization, and association with pathogenicity, we conclude that $C$. michiganensis subsp. sepedonicus elicits a typical HR in tobacco.

The relatively high concentrations of cells used to obtain an HR with $C$. michiganensis subsp. sepedonicus are similar to concentrations needed for some other bacterial species. We used either $3 \times 10^{8} \mathrm{CFU} / \mathrm{ml}$ for bacteria resuspended in phosphate buffer or $1.3 \times 10^{9} \mathrm{CFU} / \mathrm{ml}$ for bacteria resuspended in water. In an extensive study of variables influencing the HR induced by gramnegative bacteria (32), two of the strains tested required $10^{9} \mathrm{CFU} / \mathrm{ml}$ to cause an HR on cv. Glurk tobacco, whereas under certain conditions other strains caused an HR with as low as $10^{6} \mathrm{CFU} / \mathrm{ml}$. One possible concern with the high levels of bacteria we used is that, in some cases, compatible bacteria ( $P$. syringae pv. tabaci) at high concentrations may produce HR-like necroses (37). In addition, with proper manipulation it is possible to induce necrosis in tobacco with nonpathogenic $P$. fluorescens (40). However, even at very high bacterial concentrations $\left(8 \times 10^{9}\right.$ cells per $\left.\mathrm{ml}\right)$ in water or phosphate buffer, we found that nonpathogenic strains never caused an HR. Therefore, the necrotic reaction induced by virulent strains of $C$. michiganensis subsp. sepedonicus on tobacco is probably not an artifact of the high levels of bacterial inoculum used.

Only CCS prepared from virulent strains of $C$. michiganensis subsp. sepedonicus elicited the HR, which was the same in appearance and timing as that obtained with whole bacterial cells. The HR-inducing activity was protease sensitive and heat stable. Additionally, ammonium sulfate-precipitated proteins from nonpathogenic strain Cs4 produced no reaction on tobacco, even at concentrations $10 \times$ higher than that needed to obtain an HR with virulent strain CIC31, confirming the correlation between virulence and HR induction.

To demonstrate that the reaction induced by this elicitor preparation is an active plant defense response rather than a toxic response, we confirmed the necessity for active plant metabolism

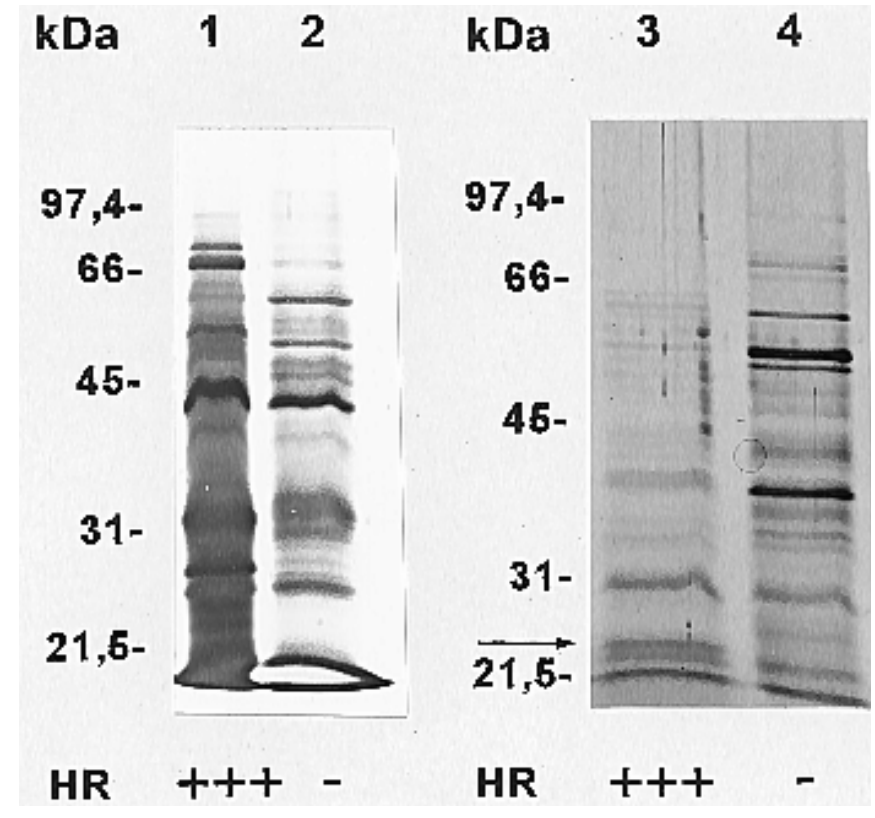

Fig. 3. Sodium dodecyl sulfate- $10 \%$ polyacrylamide gel of cellfree culture supernatant proteins from virulent and nonpathogenic Clavibacter michiganensis subsp. sepedonicus strains (protein loaded in micrograms). Lane 1, strain CIC31 $(11.4 \mu \mathrm{g})$; lane 2, strain CS3NM $(11.9 \mu \mathrm{g})$. Lanes 3 and 4, proteins eluting from DEAE at $250 \mathrm{mM} \mathrm{NaCl}$. Lane 3, from strain CIC31 $(<0.35 \mu \mathrm{g})$; lane 4, from strain CS3NM $(0.84 \mu \mathrm{g})$. Proteins were visualized by silver staining. for eliciting the HR. Coinfiltration of bacteria with various eukaryotic metabolic inhibitors has suggested that the HR is initiated by the plant and requires active plant metabolism. The availability of purified harpin $n_{\mathrm{Pss}}$ and harpin $\mathrm{Ea}_{\mathrm{Ea}}$ established with certainty that the HR requires de novo gene expression and protein synthesis, calcium flux across membranes, and ATPase activity $(29,30)$ and that the effect of the inhibitors is not due to the action of the inhibitors on the bacteria themselves. Similarly, we used four inhibitors of eukaryotic metabolism - $\alpha$-amanitin (eukaryotic RNA polymerase II inhibitor), cycloheximide (80S ribosome inhibitor), vanadate (ATPase and phosphatase inhibitor), and lanthanum (calcium channel blocker) - to show that the HR induced by the crude protein preparations from $C$. michiganensis subsp. sepedonicus is dependent on active plant metabolism. The possibility still remains that we could be observing the action of a toxin that also is dependent on plant metabolism. However, it is unlikely that a toxin would depend, as the HR does, on all four of the aspects of plant cell metabolism that are inhibited by the various chemicals used.

The most well-studied classes of bacterial HR-inducing proteins are the harpins and PopA. Harpins have been isolated from $P$. syringae pv. syringae (30), P. syringae pv. glycinea and $P$. syringae pv. tomato (49), E. amylovora (52), and E. chrysanthemi (10), and PopA has been isolated from $R$. solanacearum (5). These heat-stable proteins elicit an HR that is similar to that induced by whole cells; the proteinaceous elicitor fraction from C. michiganensis subsp. sepedonicus resembles harpins in this aspect. However, it is now clear that HR-inducing activity in bacteria is not strictly linked to harpin expression $(2,5,8)$, and the role of harpins in pathogenicity is still unclear (15). Thus, we cannot assume that the elicitor(s) described here have a clear role in either pathogenicity or induction of HR by whole cells.

One important difference between the $C$. michiganensis subsp. sepedonicus elicitor fraction and harpins is that some of the harpins are expressed only in specific minimal media $(4,30,52)$. We were fortunate that the $C$. michiganensis subsp. sepedonicus elicitor activity is expressed in rich medium, because $C$. michiganensis subsp. sepedonicus grows very slowly on minimal agar medium and not at all in minimal liquid medium.

A purification step that has been useful with harpins from $P$. syringae pv. syringae (30) and E. amylovora (52) is to remove denatured proteins by centrifugation after heat treatment, leaving behind little other than the elicitor protein. This was not useful for C. michiganensis subsp. sepedonicus, because we never saw significant differences on SDS-PAGE between heat-treated, centrifuged samples and nontreated samples (data not shown). Using bovine serum albumin as a carrier to coprecipitate denatured proteins did not improve purification.

Even nonmucoid strains of $C$. michiganensis subsp. sepedonicus produce substantial quantities of extracellular polysaccharides (EPS) (31,53). Removal of EPS obviously is necessary to purify proteins from CCS, and in fact, we found that CCS proteins failed to fractionate when run on three different microscale high pressure liquid chromatography column types (strong anion exchange, gel filtration, and hydrophobic interactions columns). We found that the best way to fractionate proteins and remove EPS was to purify the proteins on DEAE cellulose with a sodium chloride gradient. Most EPS eluted with the void volume or at low salt $(<150 \mathrm{mM})$, whereas proteins eluted at $200 \mathrm{mM} \mathrm{NaCl}$ and higher. The majority of the HR-eliciting activity was eluted in the $250 \mathrm{mM} \mathrm{NaCl}$ fraction, which contained very little EPS (data not shown). A comparison of proteins in the $250 \mathrm{mM} \mathrm{NaCl}$ fractions from virulent and nonpathogenic strains shows a few minor differences, plus one major band difference at $\sim 25 \mathrm{kDa}$ that is only in the virulent strain. This could be a candidate for an elicitor protein.

Harpins, as well as other virulence factors, are exported from gram-negative cells by the hrp (or type III) secretion apparatus. Although the elicitor(s) described here bear a superficial resemblance to harpins, any suggestion of the existence of an hrp locus 
in $C$. michiganensis subsp. sepedonicus must consider the difference between the gram-negative and -positive cell wall. Although there is precedent for homologous transport systems in grampositive and -negative bacteria (47), the gram-positive systems must have modifications to allow for the single cell membrane. A system in gram-positive pathogens homologous to the hrp system might be expected to conserve only the components involved in transport through the inner membrane (e.g., hrcV, hrcR, hrcS, hrcT, and hrcU $[12,15])$. Alternatively, due to the considerable genetic distance between gram-negative and -positive bacteria, it is reasonable to suggest that this elicitor protein could be secreted through an unrelated secretion system.

Determining the role of HR-eliciting factors in C. michiganensis subsp. sepedonicus infection will be difficult, because approaches for mutagenesis and complementation are limited for this species (44). Reverse genetics, in which a purified protein is sequenced at the amino acid level and used to identify the corresponding gene, have been instrumental in cloning genes from organisms that are recalcitrant to genetic manipulation. Thus, the finding that an HR can be elicited by a proteinaceous fraction from $C$. michiganensis subsp. sepedonicus provides an obvious route to isolating genes that may have a role in HR induction by $C$. michiganensis subsp. sepedonicus.

\section{ACKNOWLEDGMENTS}

This work was supported by the Finnish Academy and by Colorado Agricultural Experiment Station Grant 620. R. Nissinen was supported by fellowships from the Jenny and Antti Wihuri Foundation, the Finnish Konkordia Foundation, and the TOP Foundation.

\section{LITERATURE CITED}

1. Alfano, J. R., Bauer, D. W., Milos, T. M., and Collmer, A. 1996. Analysis of the role of the Pseudomonas syringae pv. syringae HrpZ harpin in elicitation of the hypersensitive response in tobacco using functionally non-polar hrpZ deletion mutations, truncated HrpZ fragments and hrmA mutations. Mol. Microbiol. 19:715-728.

2. Alfano, J. R., and Collmer, A. 1996. Bacterial pathogens in plants: Life up against the wall. Plant Cell 8:1683-1698.

3. Arlat, M., Gough, C. L., Barger, C. E., Boucher, C., and Daniels, M. J. 1991. Xanthomonas campestris contains a cluster of hrp genes related to the larger hrp cluster of Pseudomonas solanacearum. Mol. Plant-Microbe Interact. 4:593-601.

4. Arlat, M., Gough, C. L., Zischek, C., Bargeris, P. A., Trigalet, A., and Boucher, C. A. 1992. Transcriptional organization and expression of the large hrp gene cluster of Pseudomonas solanacearum. Mol. Plant Microbe Interact. 5:187-193.

5. Arlat, M., Van Gijsegem, F., Huet, J. C., Pernollet, J. C., and Boucher, C. A. 1994. PopA1, a protein which induces a hypersensitivity-like response on specific Petunia genotypes, is secreted via the hrp pathway of Pseudomonas solanacearum. EMBO J. 13:543-553.

6. Ausubel, F. M., Brent, R., Kingston, R. E., Moore, D. D., Seidman, J. G., Smith, J. A., and Struhl, K. 1995. Current protocols in Molecular Biology. Vol. 2. John Wiley \& Sons, New York.

7. Baer, D., and Gudmestad, N. C. 1993. Serological detection of nonmucoid strains of Clavibacter michiganensis subsp. sepedonicus in potato. Phytopathology 83:157-163.

8. Barny, M.-A. 1995. Erwinia amylovora hrp N mutants, blocked in harpin synthesis, express a reduced virulence on host plants and elicit variable hypersensitive reactions on tobacco. Eur. J. Plant Pathol. 101:333-340.

9. Bauer, D. W., and Beer, S. V. 1991. Further characterization of an hrp gene cluster of Erwinia amylovora. Mol. Plant-Microbe Interact. 4:493499.

10. Bauer, D. W., Wei, Z.-M., Beer, S. V., and Collmer, A. 1995. Erwinia chrysanthemi harpin $_{E c h}$ : An elicitor of the hypersensitive response that contributes to soft-rot pathogenesis. Mol. Plant-Microbe Interact. 8:484491.

11. Bishop, A. L., and Slack, S. A. 1987. Effect of inoculum dose and preparation, strain variation, and plant growth conditions on the eggplant bioassay for bacterial ring rot. Am. Pot. J. 64:227-234.

12. Bogdanove, A. J., Beer, S. V., Bonas, U., Boucher, C. A., Collmer, A., Coplin, D. L., Cornelis, G. R., Huang, H.-C., Hutcheson, S. W., Panopoulos, N. J., and Van Gijsegem, F. 1996. Unified nomenclature for broadly conserved hrp genes of phytopathogenic bacteria. Mol. Microbiol. 20:681-683.

13. Bonas, U., Schulte, R., Fenselau, S., Minsavage, G. V., Staskawicz, B. J., and Stall, R. E. 1991. Isolation of a gene cluster from Xanthomonas campestris pv. vesicatoria that determines pathogenicity and the hypersensitive response on pepper and tomato. Mol. Plant-Microbe Interact. 4:8188 .

14. Boucher, C. A., Van Gijsegem, F., Barberis, P. A., Arlat, M., and Zischek, E. 1987. Pseudomonas solanacearum genes controlling both pathogenicity and hypersensitivity on tobacco are clustered. J. Bacteriol. 169:56265632.

15. Collmer, A., Alfano, J. R., Bauer, D. W., Preston, G. M., Loniello, A. O., Conlin, A., Ham, J. H., Huang, H.-C., Gopalan, S., and He, S. Y. 1996. Secreted proteins, secretion pathways, and the plant pathogenicity of Erwinia chrysanthemi and Pseudomonas syringae. Pages 159-164 in: Biology of Plant-Microbe Interactions. G. Stacey, B. Mullin, and P. M. Gresshoff, eds. International Society for Plant-Microbe Interactions, St. Paul, MN.

16. Davis, M. J., Gillespie, A. G., Jr., Vidaver, A. K., and Harris, R. W. 1984. Clavibacter: A new genus containing some phytopathogenic coryneform bacteria, including Clavibacter xyli subsp. xyli sp. nov., subsp. nov. and Clavibacter xyli subsp. cynodontis subsp. nov., pathogens that cause ratoon stunting disease of sugarcane and Bermudagrass stunting disease. Int. J. Syst. Bacteriol. 34:107-117.

17. De Boer, S. H., and Copeman, R. J. 1980. Bacterial ring rot testing with the direct fluorescent antibody staining procedure. Am. Potato J. 57:457465.

18. De Boer, S. H., and McCann, M. 1990. Detection of Corynebacterium sepedonicum in potato cultivars with different propensities to express ring rot symptoms. Am. Pot. J. 67:685-695.

19. De Boer, S. H., Stead, D. E., Alivizatos, A. S., Janse, J. D., Van Vaerenbergh, J., De Haan, T. L., and Mawhinney, J. 1994. Evaluation of serological tests for detection of Clavibacter michiganensis subsp. sepedonicus in composite potato stem and tuber samples. Plant Dis. 78:725-729.

20. De Boer, S. H., Van Vaerenbergh, J., Stead, D. E., Janse, J. D., and McKenzie, A. R. 1992. A comparative study in five laboratories on detection of Clavibacter michiganensis subsp. sepedonicus in potato stems and tubers. Potato Res. 35:217-226.

21. Drennan, J. L., Westra, A. A. G., Slack, S. A., Delserone, L. M., and Collmer, A. 1993. Comparison of a DNA hybridization probe and ELISA for the detection of Clavibacter michiganensis subsp. sepedonicus in field-grown potatoes. Plant Dis. 77:1243-1247.

22. Dubois, M., Gilles, K. A., Hamilton, J. K., Rebers, P. A., and Smith, F. 1958. Colorimetric method for determination of sugars and related substances. Anal. Chem. 28:350-356.

23. Gamard, P., and De Boer, S. H. 1995. Evaluation of antagonistic bacteria for suppression of bacterial ring rot of potato. Eur. J. Plant Pathol. 101: 519-525.

24. Gitaitis, R. D. 1990. Induction of a hypersensitivelike reaction in fouro'clock by Clavibacter michiganensis subsp. michiganensis. Plant Dis. 74:58-60.

25. Goodman, R. N., and Novacky, A. 1994. The Hypersensitive Reaction in Plants to Pathogens: A Resistance Phenomenon. The American Phytopathological Society, St. Paul, MN.

26. Gopalan, S., and He, S. Y. 1996. Bacterial genes involved in the elicitation of hypersensitive response and pathogenesis. Plant Dis. 80:604610 .

27. Gudmestad, N. C. 1987. Recommendations of the national task force for the eradication of bacterial ring rot. Am. Pot. J. 64:695-697.

28. Gudmestad, N. C., Baer, D., and Kurowski, C. J. 1991. Validating immunoassay test performance in the detection of Corynebacterium sepedonicum during the growing season. Phytopathology 81:475-480.

29. He, S. Y., Bauer, D. W., Collmer, A., and Beer, S. 1994. Hypersensitive response elicited by Erwinia amylovora harpin requires active plant metabolism. Mol. Plant-Microbe Interact. 7:289-292.

30. He, S. Y., Huang, H.-C., and Collmer, A. 1993. Pseudomonas syringae

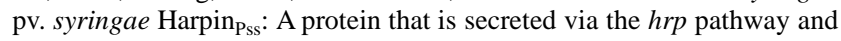
elicits the hypersensitive response in plants. Cell 73:1255-1266.

31. Henningson, P. J., and Gudmestad, N. C. 1993. Comparison of exopolysaccharides from mucoid and nonmucoid strains of Clavibacter michiganensis subsp. sepedonicus. Can. J. Microbiol. 39:291-296.

32. Hildebrand, D. C., and Riddle, B. 1971. Influence of environmental conditions on reactions induced by infiltration of bacteria into plant leaves. Hilgardia 41:34-43.

33. Horsfall, J. G., and Barratt, R. W. 1945. An improved grading system for measuring plant disease. (Abstr.) Phytopathology 35:655.

34. Hu, X., Lai, F.-M., Reddy, S. S. M., and Ishimaru, C. 1995. Quantitative detection of Clavibacter michiganensis subsp. sepedonicus by competitive polymerase chain reaction. Phytopathology 85:1468-1473.

35. Ishimaru, C. A., Lapitan, N. L. V., Van Buren, A., Fenwick, A., and Pedas, 
K. 1994. Identification of parents suitable for mapping of immunity and resistance genes in Solanum species. Am. Pot. J. 71:517-533.

36. Klement, Z. 1963. Rapid detection of pathogenicity of phytopathogenic pseudomonads. Nature (Lond.) 199:299-300.

37. Klement, Z. 1982. Hypersensitivity. Pages 149-177 in: Phytopathogenic Prokaryotes. Vol. 2. M. S. Mount and G. H. Lacy, eds. Academic Press, New York.

38. Laine, M. J., Nakhei, H., Dreier, J., Lehtilä, K., Meletzus, D., Eichenlaub, R., and Metzler, M. C. 1996. Stable transformation of the gram-positive phytopathogenic bacteria Clavibacter michiganensis subsp. sepedonicus with several cloning vectors. Appl. Environ. Microbiol. 62:1500-1506.

39. Lindgren, P. B., Peet, R. C., and Panopoulos, N. J. 1986. Gene cluster of Pseudomonas syringae pv. phaseolicola controls pathogenicity of bean plants and hypersensitivity on nonhost plants. J. Bacteriol. 168:512-522.

40. Lovrekovich, L., and Lovrekovich, H. 1970. Tissue necrosis in tobacco caused by a saprophytic bacterium. Phytopathology 60:1279-1280.

41. Manzer, E. E., Gudmestad, N. C., and Nelson, G. A. 1987. Factors affecting infection, disease development, and symptom expression of bacterial ring rot. Am. Pot. J. 64:671-676.

42. McDonald, J., and Borrel, B. 1991. Development of post harvest testing in Canada. Am. Pot. J. 68:115-121.

43. Meletzus, D., and Eichenlaub, R. 1991. Transformation of the phytopathogenic bacterium Clavibacter michiganense subsp. michiganense by electroporation and development of a cloning vector. J. Bacteriol. 173: 184-190.

44. Metzler, M. C., Laine, M. J., and De Boer, S. H. 1997. The status of molecular biological research on the plant pathogenic genus Clavibacter FEMS Microbiol. Lett. 150:1-8.

45. Metzler, M. C., Zhang, Y. P., and Chen, T. A. 1992. Transformation of the gram-positive bacterium Clavibacter xyli subsp. cynodontis by electroporation with plasmids from the IncP incompatibility group. J. Bacteriol. 174:4500-4503.
46. Niepold, F., Anderson, D., and Mills, D. 1985. Cloning determinants of pathogenesis from Pseudomonas syringae pathovar syringae. Proc. Natl. Acad. Sci. USA 82:406-410.

47. Payne, J. W., and Smith, M. W. 1994. Peptide transport by micro-organisms. Adv. Microb. Physiol. 36:1-80.

48. Pirhonen, M. U., Lidell, M. C., Rowley, D. L., Lee, S. W., Jin, S., Liang, Y., Silverstone, S., Keen, N. T., and Hutcheson, S. W. 1996. Phenotypic expression of Pseudomonas syringae avr genes in E. coli is linked to the activities of the hrp-encoded secretion system. Mol. Plant-Microbe Interact. 9:252-260.

49. Preston, G., Huang, H.-C., He, S. Y., and Collmer, A. 1995. The HrpZ proteins of Pseudomonas syringae pvs. syringae, glycinea, and tomato are encoded by an operon containing Yersinia ysc homologs and elicit the hypersensitive response in tomato but not soybean. Mol. Plant-Microbe Interact. 8:717-732.

50. Sambrook, J., Fritsch, E. F., and Maniatis, T. 1989. Molecular Cloning: A Laboratory Manual. 2nd ed. Cold Spring Harbor Laboratory Press, Cold Spring Harbor, NY.

51. Vidaver, A. K. V. 1967. Synthetic and complex media for rapid detection of fluorescence of phytopathogenic pseudomonads: Effect of carbon source. Appl. Microbiol. 15:1523-1524.

52. Wei, Z.-M., Laby, R. J., Zumoff, C. H., Bauer, D. W., He, S. Y., Collmer, A., and Beer, S. V. 1992. Harpin, elicitor of the hypersensitive response produced by the plant pathogen Erwinia amylovora. Science 257:85-88.

53. Westra, A. A. G., and Slack, S. A. 1992. Isolation and characterization of extracellular polysaccharide of Clavibacter michiganensis subsp. sepedonicus. Phytopathology 82:1193-1199.

54. Westra, A. A. G., and Slack, S. A. 1994. Effect of interaction of inoculum dose, cultivar, and geographic location on the magnitude of bacterial ring rot symptom expression in potato. Phytopathology 84:228-235.

55. Zeller, W., and Xie, Y. 1985. Studies on the diagnosis of bacterial ring rot of potatoes: Pathogenicity test on eggplants. Phytopathol. Z. 112:198-206. 